\title{
INVESTIGATING THE CO-CONNECTION BETWEEN \\ URBAN IMAGES AND THE PREVALENCE OF CRIME INCIDENCE IN CALABAR, CROSS RIVER STATE NIGERIA
}

\author{
Being A Research Project Undertaking for Tertiary Education Trust \\ Fund(TETFUND Abuja Nigeira) \\ Ubi Arikpo Ettah ${ }^{\mathrm{a}}$ Victor Mbaying Ogar ${ }^{\mathrm{b}} \mathrm{James}_{\text {Lucia Akim}}{ }^{\mathrm{c} *}$ \\ abmadu@yahoo.com \\ ${ }^{a}$ Department of Social Science Education, Cross River State College of Education, Akamkpa \\ ${ }^{b}$ Department of Social Science Education, Cross River State College of Education, Akamkpa \\ ${ }^{c}$ Department of Social Science Education ,Cross River State College of Education, Akamkpa
}

\begin{abstract}
In recent time, urban crime wave have been on the increases in the metropolis of Calabar and environments. The incidence rate is variegated in time and space. The spatial variation or sporadicity dimension is one source of concern as well as the temporal prevalence considering bogus scope of the two parameters the research team settled for the spatial perspectives which informs the choice of the research title " coconnection between crime prevalence and urban images in Calabar Cross River State" Accordingly, for meaningful and representative coverage the study area was demarcated in city blocks on the paraphenalia of land use/landscape images. From this, urban crime matrix was developed based on filed data collected from the designated locales. A single hypothesis was formulated for data analysis using the technique of chi-square $\left(\mathrm{x}^{2}\right)$ statistical analysis. The result showed that there was a significant variation in crime wave prevalence inline with urban environmental images in the result therefore was conformal with the geodemograpghic" model of Oluwole and Ojo (2018) which state that similar people with similar characteristics are likely to occupy similar or the same geographic space or locality. This insight lays a solid foundation and urban environmental planning generally.
\end{abstract}

Keyword: Co-Connection Between Urban Images, Prevalence of Crime Incidence, Environment.

\section{Executive summary}

This study focused on investigation of the co-connection between prevalence of crime incidence rate and the nature of the urban landuse /landscape characteristics in the city of Calabar, Cross River State, Nigeria. For adequate achievement of its objective the city domain was speciated into urban images categories such as: 
Urban institutional areas, urban industrial centres, urban residential, urban commercial and soon. This approach is informed by the philosophy of "unity of nature" or the earlier recognition of the bond between man and land.

Data acquisition from the field was achieved through use of the questionnaire which was structured on the basis of frequency of occurrence of crime incidence in the sampled locations. Following the purpose of the study, only single parameter objective was employed for hypothesis testing based on the technique of chi square $\left(\chi^{2}\right)$. The stated hypothesis directed attention to an evaluation of whether crime incidence rate is global in the area of the context of area of study or relative or restricted to particular area. The finding revealed that crime incidence rate is a function of the environmental image.

\section{Introduction}

Urban image analysis has remiand a key factor among behavioural scientists the world over. This follows from the recognition that the urban environment is a cultural hearth which forms the melting point of people with individual geographies", Giould and White(1974) devoted attention to the essence of individual geographies creating what is called ecological isotopes which explains the essence of neighbourhood identities in the urban livelihood domains. In a more express statement, people aggregate on the bases of commonality of identities based on status, attitudes, taste and fashion.

The urban-image explanation is renderred on the premise of how the people and place are identical. Okoye (1981) in his study of the Enugu landscape and social environment had concluded that there is a close resemblance between people and place. There may be no more flogging of the above position but simply the essence of the current investigation remained the necessarily of practically establishing such a link between crime incidence and place characteristics on Calabar, Cross River State.

\section{Statement of the problem}

Urban images refer to the different paraphernalia' of the urban bio-physical and socio-cultural environment. In this case the image conception is seen in a gross form. It encapsulates the entire fabric of the urban social and physical environment. Life modes within the city epitomizes a kaleidoscope of disparity which predicates on human sensation within the variegated social and physical environmental milieux contained in the city locales. Behavioural patterns are shaped and manifested according to the individual geographies or mental maps.

Mental cognition and behaviour of individuals or groups are manifested according to their elicited stimuli or interest. The overall corpus of human action in the urban context are a function of their image perception. Here lies the milieu context. It is this enigmatic scenario that informs the divergent description of urban images by scholars in the study of' urban environmental management. Somewhere it is described as that which raises man above the level of barbarism, the apex of civilization, the glorious accumulation of human intelligence, a liberating experience. From its alternative, negative conception, it is seen as place more akin to hell, a great wen, an anthill of human deprivation and loneliness, a trap, a cosmopolis or necropolis (Ley 1974).

From the above polar positions held about the city or urban area of any place, it is at once evident that the city or urban area of any place, is a combination of good and bad, a container of comfort and stress, an amalgam of competitive struggle for Survival where the "fittest" strives while the weaker ones are eliminated. By our submission and study as presented in this paper, urban images are positive and negative. They are physical and social. They are tangible and intangible. It is these disparity in the Personality of the place that places a challenge which demands an enquiry which propels our interest of this study.

Calabar urban environmental image is equally conceptualized as stated above. Crime prevalence embodies many other environmental behaviour modes.

This paper intends to explore the spatial and temporal occurrence of the crime wave incidence in the study area. 


\section{Purpose and objectives of the study \\ Purpose of the study}

The purpose of this study is to investigate how urban landscape and social characteristics contribute to the prevalence of crime in the metropolis of Calabar.

\section{Objectives of the study}

The study isolated a single parameter index for the investigation of crime incidence, thus the specific of objective of the study is stated below:

To examine how crime incidence is related to the nature of urban physical and social imagery.

Justification of' the study

In today's globalized world, the role of urban centres/cities in world affairs cannot be undermined. The city's gravitating force on its ecological threshold remains over bearing with grievous implications for the social and ecological sustainability of areas. As earlier stated in the problem statement, the city environment is characterized by a mosaic of life forms and activities, that characterise the distinct images of the environments. On this premise, it can be correctly said that different environment exist within the broad scale environment of each city such as the case of Calabar Nigeria.

The fundamental starting point in validating the essence of this study is the quest for understanding of how individual perception can influence his behaviour in an environmental context. In this sense, this study fits into the category of image studies which aim at adequate understanding of man- environment relationship (Hudson and Pocock 1975). The study is equally valid in adequate appreciation of man-man relationship in the urban context. This study has a wide application in several spheres of urban environmental management such as: industrial location studies, (Pred, 1967), migration studies, (Wolpat, 1963), neighbourhood images (Lee, 198), Unique city images (Lynch 1960) etc. Broadly, it is said that image studies are of immense significance due to its concern with human behaviour within the range of spatial environment Social aggregation/urban landuse models of Hans Ulman, Christaller, and Vonthunen amongst' others, conform to some geometric hierarchies in' the city locales to which the true appreciation of urban images significantly depart from. This study serves to elucidate the true picture of the neglected images of human Landscape occupants.

Urban environmental managers have a lot in store from the findings of this study in that insights will be gained about some insidious policy frameworks that may lead to disruption in social frameworks A sterling instance of such errors is the policy of 'gentrification (resettlement) which also trigger homelessness or mental dislocation. In this connection one sociologists Rossi $(1989,1990)$ drew attention of the United States government to the error of focusing more on housing development to the neglect of the need for labour and the aftermath of unemploymen etc. There is an intricate array of essence from the result of this study which can be generally stated in broad outline as follows:

- The findings may yield insights into the spatial and temporal incidents of crime in the area.

- Social workers may derive immense benefits from the capacity provided by this study in aiding their management of inherent social issues.

- Law enforcement agents will find it a useful tool in mapping their strategies of grappling with incidents of crime in the area.

- City residents and other transient Population will be adequately informed by the findings of this work on how to avoid areas designated as the "urban invisible surfaces" "Urban invisible surfaces are areas of high crime prevaleice rate that may not be kown by visitors or uninformed persons"

- Municipal authorities and urban environmental managers will further develop capacity on ways of crime detection, curbing and elimination by resorting to a clear understanding of the true precurso as of crime and addressing them accordingly. 


\section{Literature Review}

Image studies received fresh currents of attention from the domain of behavioural geography as evident in the works of Kirk (1976) White and Gould (1974) Husdson and Pocok (1975) Kofta (1935) Koliter (1947) Tolman (1952) and others.

This new thinking stemmed from the domain of behavioural psychology whith awakened interest in the 90's. Image studies were bolstered by the contribution of scholars like Lynch (1960) who in his seminar work alluded to the concept of "image of the city" from this perspective, the notion of "urban image emerged. Accordingly, it was reported that from 1960's the growing interest of geographers in environmental images became well noted more widely and deeply (Hudson and Pocok 1975) interest in image studies was rekindled based on earlier recongnition of the natural bond between man and his environment of unity of nature as putforward by Humbolt and Ritler, German philosophers or early $19^{\text {th }}$ century.

Man environmental thinking has been central to the thinking of urban environmental managers In studies derived from the basis of individual and group environmental perception which emanates from the need to evaluate human behaviour in the context of place or location. Image studies have been traced to the concern of human behaviour within the range environments can be evaluated. This can also be linked and understanding spatial processe behaviour and environmental processes are incidents that propel environmental change or transformation such weather or climate change, sunshine, rainfall, etc. These, events or trends are called phenomena (kirk 1976) Okoye's (1982) study of Okumanuw, Enugu state led to the assertion that every environment has a dual image the physical environment and the people.The implication in that proposition is that social imagery is a reflection of the physical environment and vice eversa. This clearly explains the reason why urban land characteristics is a reflection of the human characteristics involves.

This Saisfy's Wilsond (1991) allusion that the behaviour of human social system can be held to be similar to that of the physical system. The urban area in its entire conception is an area of heterogenous imagery in social and physical personalization (Udo 2000) The above conception follows the model of geodemographic classification system putforward by Oluwule and Ojo (2018) where they expounded that the system is an area classification model that simplifies a large and complex body of multivariate and multidemensoical information about people, where and how they live, work and recreate. They stated further on that geodemographic systems are developed based on geographical ontologies that similar people with similar characteristics are more likely to live within the same locality types and will be distributed in different location across geographical space (Harison, 2005) Seigh, 1997 , Barrow, 1991). This model correlates squarely with our research concept in this study landscape/urban image and crime prevelence. It goes to corroborate an existing maxim that peoples characteristic are sysnonymous to images of place. This has apty discrited by Butimer (1990) as individual geographer's or by Jones (2015) as ecologucal isotopes. Hence landscape imprints smack of cultural personalities.

The geodemographic model had earlier been visualized and conceptualised by the notion of Topophilia(sense of place) Tuan 1974). Following this, it was espoused that every continent has its great spirit of place. Every people is polarized in some localities, which is home, homeland etc. different places on the face of the earth have different effluence, different vibrations, different chemical exhalation, different polarity with different stars. This appeals directly to the notion of urban ecology.

Images(Lawrence, 2004) it was further postulated that spirit or sense of place is concerned with the relationship between place and person, an awareness of the distrinctive character of specific localities (Biggs 1970) Topophilia relates to attachment of symbolic meaning of places, relating to two dimensions of place characterization, physical and social-psychological the strenght of the physical image derived from the distinctive combination of local geography and the built form.

Place characterization underlies the essence of behavioural attribution which explains why different environments evolve different attitudes and cultures. 


\section{Research methodoology \\ Research procedure}

The research population comprises adult male and female residents permanently domiciled in the area. From these, representative samples were drawn purposively on the basis of purposively identified urban landscapes in selected clusters. From each cluster, systematic sampling was adopted in selecting members from each universe. Then stratified sampling was employed on the bases of age, sex, socio economic status and occupation. Primary and secondary sources of data will be employed in data collection. Primary source data involved the use of questionnaires, observation schedules etc while secondary source data will employed court case files, prison inmates inventory, crime diaries (if any) and other surrogate records.

Data collection was focused mainly on two attributes of environmental images such as landscapes image and social patterns.

\section{Instruments for data collection}

The following instruments was employed for data collection:

Questionnaire for eliciting surrogate information, interview schedules, checklists, digital cameras for image capturing, voiecorders for capturing oral responses from subject. Land use maps was used as guide to fact finding in the field.

\section{Population of the Study}

The population of this Study Comprised adult urban residents from the ages of twenty to eighty and above. This Population was subject to sampling as earlier explained above. The different categories of urban physical landscapes formed part of the population of this research.

The entire city delineated based on the social matric according to welfarist categories and land use categorisation. In this sense, the following images were identified such as - old residency urban central business district, urban suburbia, high class residential areas, middle class residential, low class residential urban transient population, urban commercial centres urban institutional areas and so on. Each of these clusters or locales depict a unique image of the people in space that informs the typical essence of the ecologic isotopes.

\section{Population Sampling}

Sampling in line with the characteristics of the landscape images Multistage sampling employed starting with purposive sampling which invole delineating the areas into city blocks or land Use clusters already categorised above. From each Cluster systematic sampling employed where subjects were selected based on numerical ratios of every $\mathrm{n}^{\text {th }}$ order of numeracy. Members from each clusters were selected based on such criteria as age, education, economic status and so on. Finally ramdon sampling was adopted to provide an unbiased chance for members to be so chosen.

\section{Field data collection}

Data Collection was in three phases Phase (I) demarcation field legibility assessment and reconnaissance activities.

To achieve this the entire areas were designated according to urban landscape physical characteristic and social patterns listed below:

\section{Urban image categorization}

- Urban institutional areas- schools, churches, baracks, churches, mosques, hospitals, banks, offices or admini centres.

- Urban commercial centres: markets motor parks, fuel stations, casinos oe beting

- Urban recreation centre, hospitals, studios. Fim houses, viewing centres,

- Urban residential centres: satelite locations, old residency, middle class residency, sureter sttlements and gheltos, hidiouts, bus stops transhackle.

- Urban trnsist pupllation domain: motor part stuect cornners, etc. 
Phase II was entail field data collection proper which was carried out sampled locales with strict attention to the details of field activities plan.

Phase III addressed post field review for validation and comparison of results.

This wet focused on selected representative clusters

\section{Data analysis}

Data analysis

Data was analysed based on the technique of chi-square statistical testing.

\section{Data presentetation}

Below represent crime prevalence rating in Calabar

Table 1: Crime rate matrix distributed across urban landscape images in Calabar Urban Crime Matrix Rating In Calabar Cross River State

\begin{tabular}{|c|c|c|c|c|c|c|}
\hline $\mathbf{S} / \mathbf{N}$ & Urban Image & Sub- & \multicolumn{4}{|c|}{ Crime rating index } \\
\hline & & & $\begin{array}{l}\text { VL } \\
\text { Very low }\end{array}$ & $\begin{array}{l}\text { L } \\
\text { Low }\end{array}$ & $\begin{array}{l}\mathrm{H} \\
\text { High }\end{array}$ & $\begin{array}{l}\mathrm{VH} \\
\text { Very high }\end{array}$ \\
\hline 1 & $\begin{array}{l}\text { Urban Institutional } \\
\text { Areas }\end{array}$ & $\begin{array}{l}\text { Schools } \\
\text { Churches } \\
\text { Banks } \\
\text { Hospital }\end{array}$ & $\begin{array}{l}6 \\
3 \\
6 \\
4\end{array}$ & $\begin{array}{l}5 \\
5 \\
7 \\
4\end{array}$ & $\begin{array}{l}6 \\
8 \\
4 \\
7\end{array}$ & $\begin{array}{l}3 \\
4 \\
3 \\
5\end{array}$ \\
\hline 2 & $\begin{array}{l}\text { Urban commercial } \\
\text { centres }\end{array}$ & $\begin{array}{l}\text { Markets } \\
\text { Motor parks } \\
\text { Fuel stations } \\
\text { Casinos/beti } \\
\text { ng }\end{array}$ & $\begin{array}{l}2 \\
1 \\
3 \\
1\end{array}$ & $\begin{array}{l}2 \\
3 \\
5 \\
3\end{array}$ & $\begin{array}{l}8 \\
10 \\
8 \\
9\end{array}$ & $\begin{array}{l}8 \\
6 \\
4 \\
7\end{array}$ \\
\hline 3 & $\begin{array}{l}\text { Urban recreation } \\
\text { centres }\end{array}$ & $\begin{array}{l}\text { Hotels } \\
\text { Studio } \\
\text { Viewing } \\
\text { centres } \\
\text { Film } \\
\text { house/night } \\
\text { club }\end{array}$ & $\begin{array}{l}3 \\
4 \\
3 \\
2\end{array}$ & $\begin{array}{l}4 \\
2 \\
3 \\
2\end{array}$ & $\begin{array}{l}8 \\
6 \\
8 \\
9\end{array}$ & $\begin{array}{l}5 \\
8 \\
6 \\
7\end{array}$ \\
\hline 4 & $\begin{array}{l}\text { Urban residential } \\
\text { areas }\end{array}$ & $\begin{array}{l}\text { High class } \\
\text { Residential } \\
\text { Middle class } \\
\text { Slum areas }\end{array}$ & $\begin{array}{l}4 \\
3 \\
2 \\
1\end{array}$ & $\begin{array}{l}5 \\
6 \\
3 \\
1 \\
\end{array}$ & $\begin{array}{l}10 \\
8 \\
10 \\
12\end{array}$ & $\begin{array}{l}1 \\
3 \\
5 \\
6\end{array}$ \\
\hline 5 & $\begin{array}{l}\text { Toursit/transit } \\
\text { zones }\end{array}$ & $\begin{array}{l}\text { Marina } \\
\text { NPA } \\
\text { Airport } \\
\text { Beach }\end{array}$ & $\begin{array}{l}3 \\
4 \\
5 \\
2\end{array}$ & $\begin{array}{l}6 \\
2 \\
2 \\
3\end{array}$ & $\begin{array}{l}8 \\
8 \\
8 \\
9\end{array}$ & $\begin{array}{l}3 \\
6 \\
5 \\
6\end{array}$ \\
\hline
\end{tabular}

Note: The crime rate matrix is achieved through field data procured through interview and other procedures in the field using structured interview schedule for each matrix point twenty respondents were interviewed based on a 4 point scale rating as: (1) low(L) (2) very (VL) (3) High (H) (4) Very High (VH).

The table was transposed to the computation of results using the technique of chi-square $\left(\mathrm{x}^{2}\right)$ 


\section{Hypothesis}

Ho: there is no significant variation in the crime rate incidence over the calabar landsacpe/landuse environmental images.

Hi:There is a significant variation in the crime rate incidence over the Calabar landscape/landuse envioenmental images.

\section{Data analysis}

Data was analysed in line with the hypothesis stated above using the chi-square statiscal techniques.

Table 1: Chi square table on crime prevalence rating in Calabar

\begin{tabular}{|c|c|c|c|c|}
\hline$O_{i j}$ & $E_{i j}$ & $\left(O_{i j}-E_{i j}\right)$ & $\left(O_{i j}-E_{i j}\right)^{2}$ & $\frac{\left(O_{i j}-E_{i j}\right)^{2}}{E_{i j}}$ \\
\hline 6 & 5 & 1 & 1 & 0.20 \\
\hline 5 & 5 & 0 & 0 & 0.00 \\
\hline 6 & 6 & 0 & 0 & 0.00 \\
\hline 3 & 4 & -1 & 1 & 0.25 \\
\hline 3 & 5 & -2 & 4 & 0.80 \\
\hline 5 & 5 & 0 & 0 & 0.00 \\
\hline 8 & 6 & 2 & 4 & 0.67 \\
\hline 4 & 4 & 0 & 0 & 0.00 \\
\hline 6 & 5 & 1 & 1 & 0.20 \\
\hline 7 & 5 & 2 & 4 & 0.80 \\
\hline 4 & 6 & -2 & 4 & 0.67 \\
\hline 3 & 4 & -1 & 1 & 0.25 \\
\hline 4 & 5 & -1 & 1 & 0.20 \\
\hline 4 & 5 & -1 & 1 & 0.20 \\
\hline 7 & 6 & 1 & 1 & 0.17 \\
\hline 5 & 4 & 1 & 1 & 0.25 \\
\hline$\chi^{2}$ & & & & 4.66 \\
\hline 2 & 2 & 0 & 0 & 0.00 \\
\hline 2 & 3 & 1 & 1 & 0.33 \\
\hline 8 & 9 & -1 & 1 & 0.11 \\
\hline 8 & 6 & 2 & 4 & 0.67 \\
\hline 1 & 2 & -1 & 1 & 0.50 \\
\hline 3 & 3 & 0 & 0 & 0.00 \\
\hline 10 & 9 & 1 & 1 & 0.11 \\
\hline 6 & 6 & 0 & 0 & 0.00 \\
\hline 3 & 2 & 1 & 1 & 0.50 \\
\hline 5 & 3 & 2 & 4 & 1.33 \\
\hline 8 & 9 & -1 & 1 & 0.11 \\
\hline 4 & 6 & -2 & 4 & 0.67 \\
\hline 1 & 2 & -1 & 1 & 0.50 \\
\hline 3 & 3 & 0 & 0 & 0.00 \\
\hline
\end{tabular}




\begin{tabular}{|c|c|c|c|c|}
\hline 9 & 9 & 0 & 0 & 0.00 \\
\hline 7 & 6 & 1 & 1 & 0.17 \\
\hline$x^{2}$ & & & & 5.00 \\
\hline 3 & 3 & 0 & 0 & 0.00 \\
\hline 4 & 3 & 1 & 1 & 0.33 \\
\hline 8 & 8 & 0 & 0 & 0.00 \\
\hline 5 & 7 & -2 & 4 & 0.57 \\
\hline 4 & 3 & 1 & 1 & 0.33 \\
\hline 2 & 3 & -1 & 1 & 0.33 \\
\hline 6 & 8 & -2 & 4 & 0.50 \\
\hline 8 & 7 & 1 & 1 & 0.14 \\
\hline 3 & 3 & 0 & 0 & 0.00 \\
\hline 3 & 3 & 0 & 0 & 0.00 \\
\hline 8 & 8 & 0 & 0 & 0.00 \\
\hline 6 & 7 & -1 & 1 & 0.14 \\
\hline 2 & 3 & -1 & 1 & 0.33 \\
\hline 2 & 3 & -1 & 1 & 0.33 \\
\hline 9 & 8 & 1 & 1 & 0.13 \\
\hline 7 & 7 & 0 & 0 & 0.00 \\
\hline$\chi^{2}$ & & & & 3.13 \\
\hline 4 & 3 & 1 & 1 & 0.33 \\
\hline 5 & 4 & 1 & 1 & 0.25 \\
\hline 10 & 10 & 0 & 0 & 0.00 \\
\hline 1 & 4 & -3 & 9 & 2.25 \\
\hline 3 & 3 & 0 & 0 & 0.00 \\
\hline 6 & 4 & 2 & 4 & 1.00 \\
\hline 8 & 10 & -2 & 4 & 0.40 \\
\hline 3 & 4 & -1 & 1 & 0.25 \\
\hline 2 & 3 & -1 & 1 & 0.33 \\
\hline 3 & 4 & -1 & 1 & 0.25 \\
\hline 10 & 10 & 0 & 0 & 0.00 \\
\hline 5 & 4 & 1 & 1 & 0.25 \\
\hline 1 & 3 & -2 & 4 & 1.33 \\
\hline 1 & 4 & -3 & 9 & 2.25 \\
\hline 12 & 10 & 2 & 4 & 0.40 \\
\hline 6 & 4 & 2 & 4 & 1.00 \\
\hline$x^{2}$ & & & & 10.29 \\
\hline 3 & 4 & -1 & 1 & 0.25 \\
\hline 6 & 3 & 3 & 9 & 3.00 \\
\hline 8 & 8 & 0 & 0 & 0.00 \\
\hline
\end{tabular}




\begin{tabular}{lllll}
3 & 5 & -2 & 4 & 0.80 \\
4 & 4 & 0 & 0 & 0.00 \\
2 & 3 & -1 & 1 & 0.33 \\
8 & 8 & 0 & 0 & 0.00 \\
6 & 5 & 1 & 1 & 0.20 \\
5 & 4 & 1 & 1 & 0.25 \\
2 & 3 & -1 & 1 & 0.33 \\
8 & 8 & 0 & 0 & 0.00 \\
5 & 5 & 0 & 0 & 0.00 \\
2 & 4 & -2 & 4 & 1.00 \\
3 & 3 & 0 & 0 & 0.00 \\
9 & 8 & 1 & 1 & 0.13 \\
6 & 5 & 1 & 1 & 0.20 \\
\hline$\chi^{2}$ & & & & $\mathbf{6 . 4 9}$ \\
\hline
\end{tabular}

\section{Decision rule:}

The degree of freedom $(\mathrm{R}-1)(\mathrm{C}-1)=(4-1),(4-1)=(3,3)$ At $\alpha=0.05$ level of significant and degree of freedom 3,3 . A table value of $\chi 2(0.05,3,3)=0.352$, and 0.352 if the computed $\chi^{2}$ is $>$ the table $\chi^{2}$ we reject in each of the variable tested the null hypothesis or otherwise if $\chi^{2}>0.352$ or $\chi^{2},<0.352$

\section{Results/findings}

Following the analysis of results using crime rate matrix in calabar, the null hypothesis was rejected while the alternative was accepted indicatging that there is significant variation in crime wave over the calabar landscape envioenmental images.

In line with the subvariable represented in the crime wave matrix of urban institution areas has four location as shown by the table the factor loading showed schools have .9 high values and .11 low values. This indicattes the ratio is almost $1: 1$, sugesting a parisimony in the prevalence of crime. This means is not too low not too high. Churches have a rating of .8 (low) and .12(high) indicating that crime rate is skwed in the negative direction. This maybe explained based on disguised intention where people hide under the cloak of religion to perpetrate crime. Banks have a ratio of .13 (low) and .7(hitgh). Organized security may be the possible explanation admin centres rating index per for institutional areas is on the medial note.

The second subvariable, urban coommercial centre have three majors domains as presented on the table. The index for market centres is visibly quite high as given by the.value .4 (low) and .16(high), motor parts peaked in the samerating scale of .4(low) and .16(high). Fuel station have fairly moderate crime incidence.

Urban recreation centres grossly have high incidence crime as presented in table 1 of the four locales represented crime incidence loads very high or factor analysis.

Urban residential areas generally scored quite high on crime fator scaling.

Finally, urban toutsits/transit zones have equally high factor scaling in the rating of crime.

Apart from religious institutional domain, areas identified with peak crime incident categories conform to the geodemographic hypothesis of Oluwode and Ojo (2018) which described human behaviour on the precint of geographic ontatogies that similar people with similar charateristic are likely to live within the same locality. On the countrary it is no more quite fashionable to arrogate landscape incidents to those habitating a locality for reasons enhanced information suraface (Grold and Whilte 1974) which facilitates spatial interraction of persons across nearly and distant space.

Inherently, a number of other intervening varaibles abound in the explaination of spatial incidents including crime. 


\section{Conclusion}

Landscape image and behavioural explanations have formed part of the personality and spirit of settlement planning, particularly urban environmental planning. The notion of to topiophilia or sense of place suggests that a natural bond that exist between people and environment from ealry times. Today enhanced means of mobility have loosed people from the grip of place identity. It follows therefore that in explanation of spatial event generally other considerations must be given to factors beyond the concept of immidiate locality. 


\section{References}

Briggs, A. 1973.Urban Cognitive Distance in R. Odions and en Dr. Ska(Eds) Image and environment. Academic.Chicago, 361-88.

Butimer, E.K. 1990. Social geography. Baltimore Earth Scam Publication.

Gould, R and White R. 1974. Mental maps, Penguin, Harmondsworth.

Harison, K.K. 2005. Seigh V.I. 1977 and Brow, B.E. 1991. IN Ojo ,Oluwode, A 2008. Urban Crime Policy Considerations. Institute for Service, Abuja, Nigeria.

Jones, E. 2010. Man and Environmental behaviour st.loius prentice Hal Publication.

Kirk, W. 1976. Historical Geography and the concept of behavioural Environment. Indian Geogra, J. Silver Jubila Edition, 152-60

Kirk, W. 1976. Historical Geography and the concept of behavioural environment. Indian Geography. Silver Jubilee Education, 1152-160.

Koffka, K. (1935) Principles of Westalt phychology, Kegam Paul, Tench, Truber New York

Kohler, W. 1947. Westalt Psychology. Live right, new York.

Lawrence, I.E. 1995. Psychology and living space. International Journal of Sociology (1) 25-35.

Lynch, K. 1960. The image of the city M.T Press Cambridge, Mass

Ojo, A. and Oluwole, A 2018. Urban Crime in Nigria: Trends cost and policy considerations institute for security service, Abuja Nigeria

Okoye, T. 1982. Urban Physical and Behavioural Environment of Enugu city. In the proceeding of the Nigerian Geographical Association, congress, held at University of Nigeria Nsukka Jun $1^{\text {st }}-4^{\text {th }}(1982)$

Rossi, I.E 1991. Meaning and Capability of urban form and behavoural Pattern. Image of places. Adailade.

Tolman, E.C. 1959. Principles of parposive behaviour, in S.koch(ed) psychology, : Studies of a Sciences, Vol. 5 McGraw-Hil, New York.

Tuan, Y.E. 1971. Environmental quality in four syndey Surburban Areas Social Science Urban Research unit, Australian National University, Canbewa.

Wilson, A. G. 1971. A family of spacial interraction models and associated developments Env. planning, Rev. 25 , 95-113. 